University of Nebraska - Lincoln

DigitalCommons@University of Nebraska - Lincoln

Agronomy \& Horticulture -- Faculty Publications

Agronomy and Horticulture Department

2000

\title{
Establishment of Big Bluestem and Illinois Bundleflower Mixtures with Imazapic and Imazethapyr
}

\author{
Daniel D. Beran \\ University of Nebraska-Lincoln \\ Robert A. Masters \\ University of Nebraska-Lincoln, rmasters1@unl.edu \\ Roch E. Gaussoin \\ University of Nebraska-Lincoln, rgaussoin1@unl.edu \\ Fernando Rivas-Pantoja \\ Instituto Nacional de Investigaciones Forestales y Agropecuarias, Merida, Yucatan, Mexico
}

Follow this and additional works at: https://digitalcommons.unl.edu/agronomyfacpub

Part of the Plant Sciences Commons

\footnotetext{
Beran, Daniel D.; Masters, Robert A.; Gaussoin, Roch E.; and Rivas-Pantoja, Fernando, "Establishment of Big Bluestem and Illinois Bundleflower Mixtures with Imazapic and Imazethapyr" (2000). Agronomy \& Horticulture -- Faculty Publications. 319.

https://digitalcommons.unl.edu/agronomyfacpub/319
}

This Article is brought to you for free and open access by the Agronomy and Horticulture Department at DigitalCommons@University of Nebraska - Lincoln. It has been accepted for inclusion in Agronomy \& Horticulture -Faculty Publications by an authorized administrator of DigitalCommons@University of Nebraska - Lincoln. 


\title{
FORAGE MANAGEMENT
}

\section{Establishment of Big Bluestem and Illinois Bundleflower Mixtures with Imazapic and Imazethapyr}

\author{
Daniel D. Beran, Robert A. Masters, ${ }^{*}$ Roch E. Gaussoin, and Fernando Rivas-Pantoja
}

\begin{abstract}
Weeds interfere with establishment of native grasses and legumes. A study was conducted to determine the influence of imazapic ${ }^{1}[( \pm)$ 2-[4,5-dihydro-4-methyl-4-(1-methylethyl)-5-oxo-1H-imidazol-2-yl]5-methyl-3-pyridinecarboxylic acid] and imazethapyr [2-[4,5-dihydro4-methyl - 4- (1 - methylethyl) - 5-oxo - $1 H$-imidazol - 2-yl] 5- ethyl-3 pyridinecarboxylic acid] on weed control and establishment of 'Pawnee' big bluestem (Andropogon gerardii Vitman var. gerardii Vitman) and Illinois bundleflower [Desmanthus illinoensis (Michx.) MacMill.] planted in three binary mixtures of 220:110, 165:165, and 110:220 pure live seed (PLS) $\mathrm{m}^{-2}$. Mixtures were seeded at cropland sites near Clay Center, Mead, and Lincoln, NE. Imazapic and imazethapyr were applied at $70 \mathrm{~g}$ a.i. $\mathrm{ha}^{-1}$ before planted species emerged. Imazapic or imazethapyr did not reduce dry matter yields of annual grass weeds, where herbicides were applied in April 1996 at Mead and Clay Center. Both grass and broadleaf weeds were controlled at Lincoln, where herbicides were applied in early June 1996. The herbicides usually improved big bluestem yields and total forage yields in 1996 and 1997 at all sites. Illinois bundleflower yields at Lincoln, where imazapic and imazethapyr were applied, were greater than 3.0 $\mathrm{Mg} \mathrm{ha}^{-1}$ in 1996 and 1997. In 1997, Illinois bundleflower did not survive at Mead and yielded less than $0.5 \mathrm{Mg} \mathrm{ha}^{-1}$ at Clay Center, regardless of weed control treatment or seed mixture. Imazapic and imazethapyr can improve the establishment of big bluestem and Illinois bundleflower mixtures.
\end{abstract}

$\mathrm{B}$ G BLUESTEM is a warm-season perennial grass native to the Great Plains of North America and a dominant species in tallgrass prairies (Weaver, 1954). Big bluestem provides productive, high-quality forage during midsummer, when cool-season grasses are less productive (Jung et al., 1985; Krueger and Curtis, 1979). Big bluestem is often recommended for reseeding rangeland, pastures, and marginal cropland to improve available forage, conserve soil, and provide wildlife habitat. Forage quality and yield and wildlife habitat value may be improved by planting legumes with warm-season grasses, such as big bluestem (Posler et al., 1993; Schweitzer et al., 1993; Wasser, 1982).

Several studies have demonstrated the effects of planting legumes in established warm-season grass stands. In Pennsylvania, red clover (Trifolium pratense

D.D. Beran, Dep. of Agron., University of Nebraska-Lincoln; R.A. Masters, USDA-ARS and Dep. of Agron., University of NebraskaLincoln; R.E. Gaussoin, Dep. of Horticulture, University of NebraskaLincoln, 344 Keim Hall, Lincoln, NE 68583; and F. Rivas-Pantoja, Instituto Nacional de Investigaciones Forestales y Agropecuarias, Merida, Yucatan, Mexico. Joint contribution of the USDA-ARS and the Nebraska Agric. Res. Div., Journal Series no. 12870. Received 19 Apr. 1999. *Corresponding author (rmasters@unlserve.unl.edu).

Published in Agron. J. 92:460-465 (2000).
L.), an introduced early-season legume, established well when seeded into stands of big bluestem and improved forage yields compared with areas not seeded (Jung et al., 1985). In Iowa, the quantity and seasonal distribution of forage yields were improved when established switchgrass (Panicum virgatum L.) was interseeded with the introduced early-season legumes alfalfa (Medicago sativa L.), yellow sweetclover (Melilotus officinalis Lam.), birdsfoot trefoil (Lotus corniculatus L.), and red clover (George et al., 1995). However, past work indicates that certain mixtures of early-season legumes and warm-season grasses fail because of poor grass persistence. When grown with switchgrass, alfalfa and red clover dominated mixtures by the second year (Taylor and Jones, 1983). In Kansas, cicer milkvetch (Astragalus cicer L.), a rhizomatous early-season legume with a prostrate growth habit, comprised $90 \%$ of the aboveground dry matter $1 \mathrm{yr}$ after seeding, and 100\% $4 \mathrm{yr}$ after planting when seeded with indiangrass [Sorghastrum nutans (L.) Nash], sideoats grama [Bouteloua curtipendula (Michx.) Torr.], or switchgrass. In contrast, Illinois bundleflower, a native late-season legume with an upright growth form, comprised 36,56 , and $77 \%$ of the dry matter $4 \mathrm{yr}$ after planting when seeded with indiangrass, sideoats grama, and switchgrass, respectively (Posler et al., 1993).

Illinois bundleflower has widespread distribution throughout the Great Plains (Latting, 1961) and is commonly found on mesic sites with medium-textured soils (Wasser, 1982). Illinois bundleflower has been investigated as an alternative legume for forage systems and is used in wildlife habitat plantings because of its prolific seed production (Holt, 1984; Turner et al., 1997). Seed yield from monoculture stands of Illinois bundleflower averaged $570 \mathrm{~kg} \mathrm{ha}^{-1}$ of seed over 2 yr (Piper, 1993). Illinois bundleflower improved forage yields for $4 \mathrm{yr}$ when interseeded into established kleingrass (Panicum coloratum L.) (Dovel et al., 1990) and improved forage yield and protein when seeded with switchgrass, sideoats grama, or indiangrass (Posler et al., 1993). Some evidence suggests that Illinois bundleflower may be a shortlived legume (Holt, 1984; Townsend et al., 1975) and sensitive to heavy grazing (Berg, 1990; Latting, 1961); however, natural reseeding may enhance persistence.

Binary mixtures of big bluestem and Illinois bun-

${ }^{1}$ Mention of a particular pesticide does not imply registration under FIFRA, nor does it constitute a recommendation by the University of Nebraska-Lincoln or the USDA-ARS.

Abbreviation: PLS, pure live seed. 
dleflower could provide high-quality forage during the summer on marginal cropland and degraded rangeland, but there is no information regarding weed control during establishment of these species planted in mixtures. Weed interference during establishment is a primary obstacle to establishing native legumes and warm-season grasses (Beran et al., 1999; Martin et al., 1982). Certain imidazolinone herbicides, imazethapyr and imazapic, can reduce weed interference and facilitate rapid establishment of some native legumes and warm-season grasses (Beran et al., 1999; Masters et al., 1996). Preemergence application of imazethapyr and imazapic improved establishment and dry matter yields of Illinois bundleflower and big bluestem monoculture stands (Masters et al., 1996). The imidazolinone herbicides have the potential to reduce weed interference and enable simultaneous establishment of big bluestem and Illinois bundleflower planted in binary mixtures. Our objectives were to determine the influence of imazethapyr and imazapic on weed control and establishment and yield of big bluestem and Illinois bundleflower when planted in three binary mixtures.

\section{MATERIALS AND METHODS}

Experiments were conducted in 1996 and 1997 at cropland sites at the South Central Research and Extension Center near Clay Center, NE, near Lincoln, NE, and at the University of Nebraska Agriculture Research and Development Center near Mead, NE. The approach used to produce a firm seedbed varied by site and was influenced by previous cropping history. The soil at the Clay Center site was a Hastings silt loam (fine, smectitic, mesic Udic Argiustolls) and had been planted to sorghum [Sorghum bicolor (L.) Moench] the previous year, which was treated with a preemergence application of atrazine [6 - chloro - $N$ - ethyl - $N$ ' - (1 - methylethyl ) - 1,3,5 - triazine - 2,4 diamine] at $1.6 \mathrm{~kg}$ a.i. $\mathrm{ha}^{-1}$ and metolachlor [2-chloro- $\mathrm{N}$-(2ethyl-6-methylphenyl)- $\mathrm{N}$-(2-methoxy-1-methylethyl)acetamide] at $2.0 \mathrm{~kg}$ a.i. $\mathrm{ha}^{-1}$. The seedbed was disked, harrowed, and cultipacked in preparation for planting. The soil at the Lincoln site was a Sharpsburg silty clay loam (fine, smectitic, mesic Typic Argiudolls) and soybeans, which were not treated with herbicide, were grown at the site the previous year. Glyphosate [ $N$-(phosphono-methyl)glycine] was applied at 3.3 $\mathrm{kg}$ a.i. ha ${ }^{-1}$ on 21 May 1996 to control the winter annuals field pennycress (Thlaspi arvense L.), wild mustard [Brassica kaber (DC.) L.C. Wheeler], and shepherd's-purse [Capsella bursapastoris (L.) Medik.]. No soil tillage was required at the Lincoln site prior to planting. The soil at the Mead site was a Sharpsburg silty clay loam that had been fallow and was not treated with herbicide for $2 \mathrm{yr}$ leading up to experiment initiation. Annual grass residue from the previous year was removed by burning on April 15, 1996, with no soil tillage before planting.

Treatments were arranged in a split-plot design with weed control treatments applied to 8- by 5-m whole plots and big bluestem and Illinois bundleflower binary mixtures seeded to 8 - by 1.6-m subplots. Whole plots were arranged as a randomized complete block with four replications at each site. Weed control treatments were no herbicide, and imazapic and imazethapyr applied at $70 \mathrm{~g}$ a.i. $\mathrm{ha}^{-1}$. Prior to emergence of the planted species, herbicides were applied with a tractormounted sprayer at $0.28 \mathrm{MPa}$ to achieve a delivery rate of $190 \mathrm{~L} \mathrm{ha}^{-1}$. Methylated sunflower seed oil and $28 \%$ urea ammonium nitrate at $1.25 \% \mathrm{v} / \mathrm{v}$ were added to the spray solu- tion as adjuvants to enhance foliar uptake by emerged weed seedlings. Herbicide treatments were applied at Clay Center on 23 April, at Mead on 26 April, and at Lincoln on 3 June 1996.

Within each whole plot, subplots were seeded with one of three binary mixtures of Pawnee big bluestem and Illinois bundleflower. The three binary seed mixtures were planted at a total rate of $330 \mathrm{PLS} \mathrm{m}^{-2}$, with 220:110, 165:165, and 110:220 PLS $\mathrm{m}^{-2}$ ratios of big bluestem to Illinois bundleflower, respectively. Mixtures were seeded at $330 \mathrm{PLS} \mathrm{m}^{-2}$ because this rate is commonly recommended for revegetation of marginal cropland with warm-season grasses in Nebraska (Anderson, 1989). Acceptable monoculture stands of Illinois bundleflower were established when seeded at $300 \mathrm{PLS} \mathrm{m}^{-2}$ (Beran et al., 1999). Seeds were planted at a 1.2-cm depth using a seven-row plot drill with an 18 -cm spacing between rows on 18 April at Mead, 23 April at Clay Center, and 22 May 1996 at Lincoln.

Before planting, big bluestem seeds were debearded and cleaned as described by Vogel et al. (1998). Illinois bundleflower seeds were not scarified, but were inoculated with the appropriate rhizobia before planting. To determine germinability and the seed weights needed to achieve the desired seeding rates, four $0.25-\mathrm{g}$ samples each of big bluestem and Illinois bundleflower seed were placed in separate plastic plates on moistened blotter paper. Plates were covered and placed in a germination chamber with an 8-h dark and 16-h light cycle with a corresponding 20 and $30^{\circ} \mathrm{C}$ diurnal temperature cycle. The number of germinated seeds was then counted at 7-d intervals for $28 \mathrm{~d}$.

In late June to early July 1996, herbicide efficacy and big bluestem and Illinois bundleflower seedling density were measured. Herbicide efficacy was assessed with visual weed control ratings based on canopy coverage reduction of the dominant weed species compared with plots that were not treated with herbicide. The dominant weeds at Clay Center were fall panicum (Panicum dichotomiflorum Michx.) and Pennsylvania smartweed (Polygonum pensylvanicum L.). Yellow foxtail [Setaria glauca (L.) Beauv.] and green foxtail [Setaria viridis (L.) P. Beauv.] were the dominants at Lincoln, and fall panicum and yellow foxtail were the dominants at Mead. Big bluestem and Illinois bundleflower seedling density was determined by counting the number of emerged seedlings in two $0.25-\mathrm{m}^{2}$ quadrats placed randomly within each subplot.

Weed species composition and dry matter yield of big bluestem, Illinois bundleflower, broadleaf weeds, and annual grass weeds were determined. Weed composition was assessed by visually estimating weed species canopy cover as described by Daubenmire (1959). To determine dry matter yield, vegetation within two randomly placed $0.25-\mathrm{m}^{2}$ quadrats in each subplot was clipped to a 2.5-cm height in 1996 on 17 August at Clay Center, on 26 August at Mead, and on 6 September at Lincoln. Herbage samples were separated into big bluestem, Illinois bundleflower, annual broadleaf weeds, and annual grass weeds, dried at $60^{\circ} \mathrm{C}$ for $72 \mathrm{~h}$, and weighed. In 1997, big bluestem and Illinois bundleflower dry matter yield and Illinois bundleflower density were assessed on 23 July at Lincoln, 13 August at Clay Center, and 18 August at Mead. The planted species were harvested using the same method as in 1996, except that locations where quadrats were placed in 1996 were avoided during quadrat placement in 1997. Illinois bundleflower density was determined by counting the number of rooted stems within each quadrat.

Study sites were burned on 8 and 10 May 1997 at Mead and Clay Center, respectively, to remove plant residue. Fire is commonly recommended to enhance new prairie plantings in the Great Plains (Anderson, 1989; Schramm, 1992). Illinois 
bundleflower was dormant and big bluestem tillers were beginning to grow at the time of burning. At Lincoln, frequent rainfall events in late April and early May 1997 prevented burning while Illinois bundleflower was dormant, so plant residue was cut to a $15-\mathrm{cm}$ height with a disc mower and removed with a rake on 9 May 1997.

To suppress weed growth that would have interfered with sampling in the second growing season, metolachlor at $2.2 \mathrm{~kg}$ a.i. $\mathrm{ha}^{-1}$ and bromoxynil [3,5-dibromo-4-hydroxy-benzonitrile] at $0.28 \mathrm{~kg}$ a.i. $\mathrm{ha}^{-1}$ were applied to all plot areas on 14 , 17, and 21 May 1997 at Mead, Clay Center, and Lincoln, respectively. Both herbicides are safe on established big bluestem and Illinois bundleflower. Metolachlor controls germinating annual grasses and is tolerated by both seedling and established big bluestem (Masters, 1995 and 1997). Seedling alfalfa and warm-season grasses tolerate bromoxynil.

Weed control, weed cover, density, and yield data were tested by analysis of variance using a split-plot model. With the exception of big bluestem and Illinois bundleflower seedling density measured in 1996, response variables were analyzed within site because several variables had site interactions and heterogeneous error variances as indicated by Hartley's $F$-max test (Hartley, 1950). Broadleaf weed yields data from Lincoln were log transformed to stabilize error variance (Lentner and Bishop, 1993). Data from significant $(P<0.05)$ highest order interactions are presented with means separated using Fisher's protected LSD at $\alpha=0.05$ (Ott, 1977).

\section{RESULTS AND DISCUSSION}

Seedling density of big bluestem and Illinois bundleflower responded similarly to herbicide treatments and seed mixtures across sites. Precipitation was above average at all sites in May 1996 (Fig. 1) and appeared to provide sufficient water for seed germination and seedling emergence. Big bluestem seedling density was
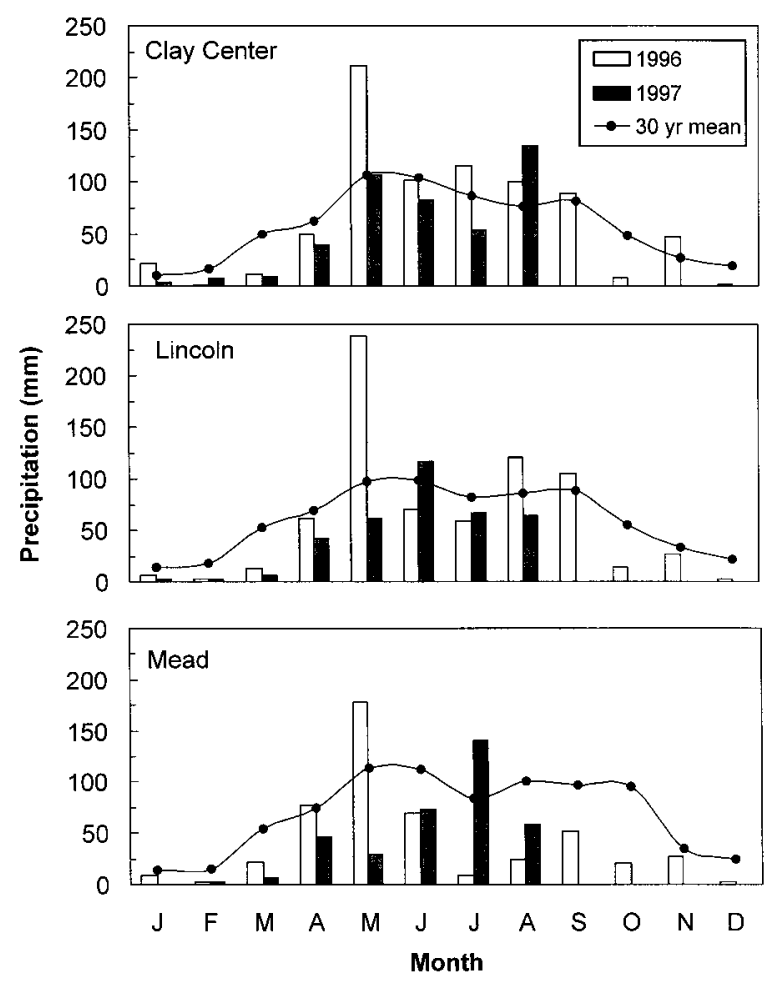

Fig. 1. Monthly precipitation from January 1996 to August 1997 and 30-yr averages at Clay Center, Lincoln, and Mead, NE. greater where imazethapyr and imazapic were applied than in areas where no herbicide was applied (Table 1). Averaged across mixtures, the density of Illinois bundleflower seedlings was similar across all weed control treatments. Seedling density of both species increased with seeding proportion and was highest when seeded at $220 \mathrm{PLS} \mathrm{m}^{-2}$. Overall weed control at this time based on canopy coverage reduction was similar on imazethapyr- and imazapic-treated areas (Table 2).

Dry matter yield of big bluestem and Illinois bundleflower and weed control measured in late summer of 1996 varied considerably by environment. At Clay Center, seeding rate did not influence big bluestem yield. Yield was greatest in imazapic-treated areas, and the combined yield of big bluestem and Illinois bundleflower surpassed $1.6 \mathrm{Mg} \mathrm{ha}^{-1}$ when treated with imazethapyr or imazapic (Table 3). A significant herbicide $\times$ seed mixture interaction was detected for Illinois bundleflower yield. Illinois bundleflower yield was improved over nontreated areas when the legume was seeded at $220 \mathrm{PLS} \mathrm{\textrm {m } ^ { - 2 }}$ and treated with either herbicide, or when seeded at $165 \mathrm{PLS} \mathrm{m}^{-2}$ and treated with imazapic. Canopy cover of Pennsylvania smartweed, broadleaf weed yield, and total weed yield at Clay Center were reduced by imazapic and imazethapyr when compared with areas where no herbicide was applied (Table 2). In contrast, fall panicum canopy cover was greater on areas treated with the imazethapyr and imazapic than on areas not treated with herbicide. Monthly precipitation at the Clay Center site in May 1996 was $100 \mathrm{~mm}$ above the 30-yr average (Fig. 1), and likely reduced the amount of herbicide present in the surface soil where fall panicum seeds were germinating in June 1996.

At the Mead site, precipitation patterns in the establishment year may have also influenced weed control and dry matter yield of big bluestem and Illinois bundleflower. Compared with 30-yr averages, precipitation in May 1996 was $65 \mathrm{~mm}$ above normal and from 1 June to 31 Aug. 1996 was $190 \mathrm{~mm}$ below normal (Fig. 1). Although imazapic and imazethapyr reduced yellow foxtail canopy cover, herbicide-treated areas had

Table 1. Density of big bluestem (BB) and Illinois bundleflower (IB) seedlings as influenced by herbicide treatment and seed mixture. $\dagger$

\begin{tabular}{lcc}
\hline Main effect & Big bluestem & \multicolumn{2}{c}{ Illinois bundleflower } \\
\cline { 2 - 3 } & \multicolumn{2}{c}{ no. $\mathbf{m}^{-2}$} \\
Herbicide treatment & & \\
Imazapic & 91 & $\mathbf{7 0}$ \\
Imazethapyr & 89 & $\mathbf{7 3}$ \\
Nontreated & 67 & $\mathrm{NS}$ \\
$\quad$ LSD (0.05) & 12 & \\
Seed mixture & & 99 \\
Mix 1§ & 61 & $\mathbf{7 3}$ \\
Mix 2 & $\mathbf{8 4}$ & $\mathbf{5 3}$ \\
Mix 3 & $\mathbf{1 0 2}$ & $\mathbf{1 2}$ \\
$\quad$ LSD (0.05) & 11 & \\
\hline
\end{tabular}

$\dagger$ Illinois bundleflower and big bluestem density were averaged across experiment locations.

$\$$ Herbicides were applied at $70 \mathrm{~g}$ a.i. ha $^{-1}$ in spring 1996 prior to emergence of the planted species.

$\S$ Mix $1=110 \mathrm{BB}+220 \mathrm{IB}$ pure live seed (PLS) $\mathrm{m}^{-2} ;$ Mix $2=165 \mathrm{BB}+$ 165 IB PLS m$^{-2}$; Mix 3 = 220 BB + 110 IB PLS m ' $^{-2}$. 
Table 2. Weed control and canopy cover of dominant weeds, and annual grass, broadleaf, and total weed yields as influenced by herbicide main effect at sites near Clay Center, Lincoln, and Mead, NE, in 1996.

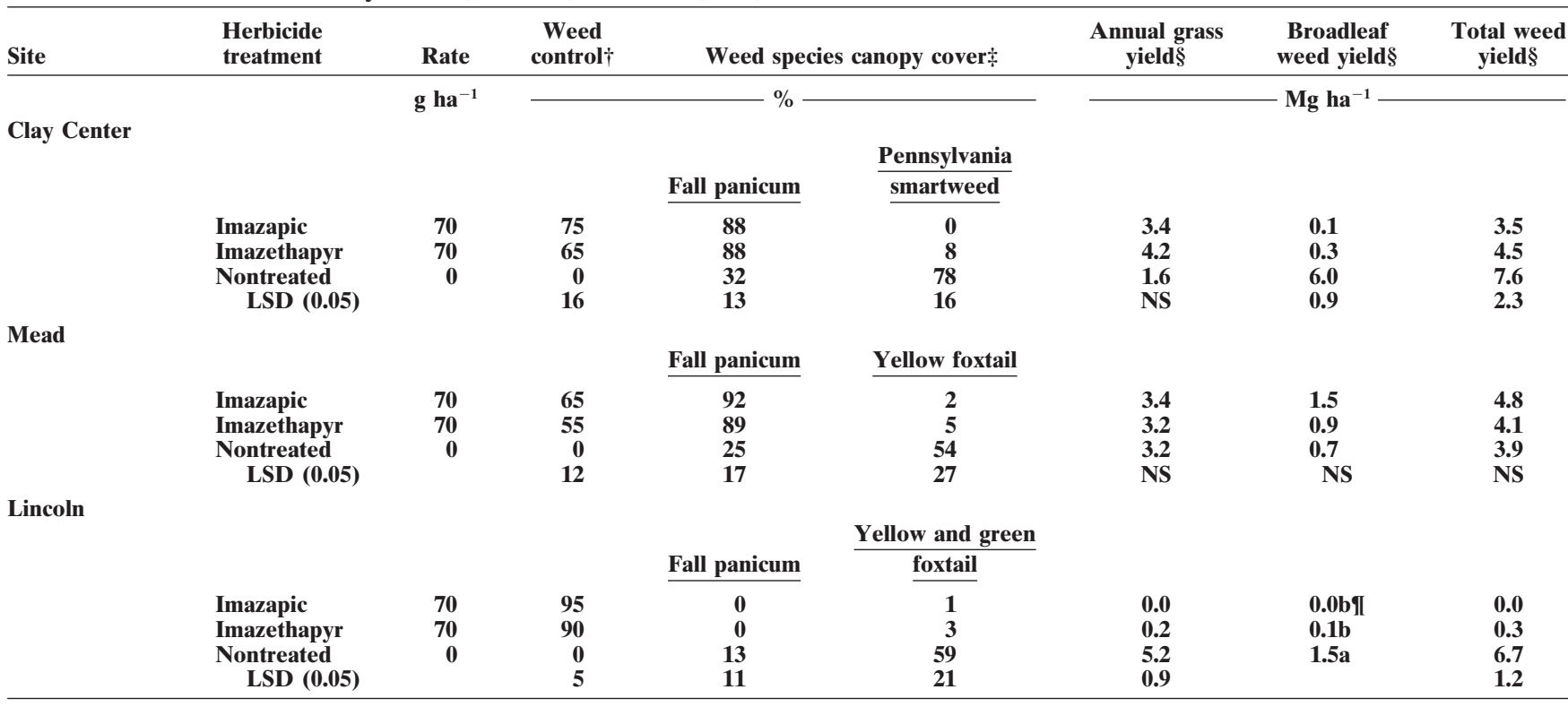

$\dagger$ Visual weed control ratings based on the reduction of total weed canopy coverage were recorded on 26 June 1996 at Clay Center, 1 July 1996 at Mead, and 8 July 1996 at Lincoln.

$\$$ Weed canopy coverage of dominant weed species were estimated on 5 Oct. 1996 at Clay Center and Lincoln, and on 30 Sept. 1996 at Mead.

$\$$ Annual grass and broadleaf weeds were sampled on 17 Aug. at Clay Center, on 26 Aug. at Mead, and on 6 Sept. 1996 at Lincoln. The dominant broadleaf weeds were Pennsylvania smartweed (Polygonum pensylvanicum L.) at Clay Center, velvetleaf (Abutilon theophrasti Medik.) at Lincoln, and tall waterhemp [Amaranthus tuberculatus (Moq.) J.D. Sauer] and common waterhemp (Amaranthus rudis Sauer) at Mead.

II Broadleaf weed yield data from Lincoln were log transformed to stabilize error variance. Nontransformed means followed by the same letters are not significantly different based on transformed mean separation with Fisher's protected LSD $(P=0.05)$.

greater fall panicum cover than nontreated areas, and annual grass yields that were similar to those in nontreated plots (Table 2). As with the Clay Center site, above-average precipitation in May 1996 may have contributed to reduce efficacy of the April-applied herbicides and control of fall panicum. Fall panicum interference combined with dry conditions from June through August likely affected first-year production of Illinois bundleflower and big bluestem in the herbicide-treated areas. Illinois bundleflower yield was less than $0.2 \mathrm{Mg}$ ha $^{-1}$ and was not improved by herbicide treatments (Table 4). Big bluestem yield was greater in imazapictreated plots than in nontreated plots. Total forage yield of Illinois bundleflower and big bluestem was improved with either imazethapyr or imazapic, but was less than $1.0 \mathrm{Mg} \mathrm{ha}^{-1}$.

Planting and herbicide application at the Lincoln site was delayed until 22 May and 3 June 1996, respectively, because rainfall events through mid-May kept the seed- bed too wet to plant. Delaying the herbicide application until after the precipitation events in May 1996 may have contributed to greater control of both annual grass and broadleaf weeds. Unlike the Mead and Clay Center sites, imazethapyr and imazapic reduced the canopy cover of fall panicum and the herbage of grass and broadleaf weeds at Lincoln (Table 2). Annual grass yields averaged less than $1.0 \mathrm{Mg} \mathrm{ha}^{-1}$ in herbicidetreated areas and 5.2 $\mathrm{Mg} \mathrm{ha}^{-1}$ where no herbicide was applied. Illinois bundleflower dry matter yields were 3.5 and $4.2 \mathrm{Mg} \mathrm{ha}^{-1}$ when treated with imazapic and imazethapyr, which were greater than the $0.2 \mathrm{Mg} \mathrm{ha}^{-1}$ produced where no herbicide was applied (Table 5). Big bluestem yields were also improved by herbicide treatments, and were greatest where imazapic was applied and big bluestem was seeded at $220 \mathrm{PLS} \mathrm{m}^{-2}$. Total forage yield of the seeded mixtures exceeded 5.5 $\mathrm{Mg} \mathrm{ha}^{-1}$ where imazethapyr or imazapic was applied.

In 1997, big bluestem and total forage yield were

Table 3. Illinois bundleflower (IB), big bluestem (BB), total forage (BB + IB) yields measured in the establishment year (1996) and the year after planting (1997) as affected by herbicide main effect or herbicide $\times$ seed mixture interaction at a site near Clay Center, NE.

\begin{tabular}{|c|c|c|c|c|c|c|c|c|c|c|c|}
\hline \multirow[b]{3}{*}{ Herbicide } & \multirow[b]{3}{*}{ Rate } & \multicolumn{5}{|c|}{1996} & \multicolumn{5}{|c|}{1997} \\
\hline & & Mix $1 \dagger$ & Mix 2 & Mix 3 & \multirow[b]{2}{*}{$\mathbf{B B} \div$} & \multirow[b]{2}{*}{$\mathbf{B B}+\mathbf{I B}+$} & \multirow[b]{2}{*}{ IB $\div$} & \multirow[b]{2}{*}{$\mathbf{B B} \div$} & Mix 1 & Mix 2 & Mix 3 \\
\hline & & & IB & & & & & & \multicolumn{3}{|c|}{$\mathbf{B B}+\mathbf{I B}$} \\
\hline & & \multicolumn{10}{|c|}{$-\operatorname{Mg~ha}^{-1}$} \\
\hline Imazapic & 70 & 0.5 & 0.4 & 0.3 & 1.8 & 2.2 & 0.1 & 6.1 & 5.1 & 7.4 & 6.2 \\
\hline Imazethapyr & 70 & 1.1 & 0.4 & 0.3 & 1.0 & 1.7 & 0.3 & 4.1 & 4.4 & 4.4 & 4.5 \\
\hline Nontreated & 0 & 0.1 & 0.1 & 0.1 & 0.2 & 0.2 & 0.1 & 1.2 & 1.5 & 1.1 & 2.6 \\
\hline LSD (0.05) & & & 0.3 & & 0.7 & 1.0 & NS & 2.2 & & 1.4 & \\
\hline
\end{tabular}

$\dagger$ Mix $1=110$ BB +220 IB pure live seed (PLS) m $^{-2}$; Mix $2=165$ BB +165 IB PLS m m $^{-2}$ Mix $3=220$ BB +110 IB PLS m ${ }^{-2}$.

$\uparrow$ Variables are averaged across seed mixtures because herbicide $\times$ seed mixture interaction was not significant. 
Table 4. Illinois bundleflower (IB), big bluestem (BB), and total forage (BB + IB) yields measured in the establishment year (1996) and the year after planting (1997) as affected by herbicide main effect at a site near Mead, NE.

\begin{tabular}{|c|c|c|c|c|c|c|c|}
\hline \multirow[b]{2}{*}{ Herbicide } & \multirow[b]{2}{*}{ Rate } & \multicolumn{3}{|c|}{1996} & \multicolumn{3}{|c|}{1997} \\
\hline & & IB & BB & $\mathbf{B B}+\mathbf{I B}$ & IB & BB & $\mathbf{B B}+\mathbf{I B}$ \\
\hline & & & & & & & \\
\hline Imazapic & 70 & 0.0 & 0.5 & 0.6 & 0 & 4.9 & 4.9 \\
\hline Imazethapyr & 70 & 0.2 & 0.3 & 0.4 & 0 & 4.2 & 4.2 \\
\hline Nontreated & 0 & 0.0 & 0.1 & 0.1 & 0 & 3.2 & 3.2 \\
\hline LSD $(0.05)$ & & NS & 0.3 & 0.3 & NS & 1.0 & 1.0 \\
\hline
\end{tabular}

consistently greater where imazethapyr or imazapic was applied in 1996 compared with no herbicide treatment. Big bluestem dry matter yield averaged 4.5, 5.1, and 7.6 $\mathrm{Mg} \mathrm{ha}^{-1}$ in herbicide-treated areas at Mead (Table 4), Clay Center (Table 3), and Lincoln (Table 5), respectively. A significant herbicide $\times$ seed mixture interaction was detected for total forage yield at Clay Center. Total dry matter yield was greatest when big bluestem was seeded at 165 or 220 PLS $\mathrm{m}^{-2}$ and treated with imazapic. At Lincoln, total forage yield where imazapic and imazethapyr were applied averaged $10.9 \mathrm{Mg} \mathrm{ha}^{-1}$, with $28 \%$ of the dry matter from Illinois bundleflower (Table 5). Total forage yield was greatest where big bluestem was seeded at $220 \mathrm{PLS} \mathrm{m}^{-2}$ and Illinois bundleflower contributed $18 \%$ of the total forage yield when averaged across herbicide treatments (Table 6). At Mead, big bluestem comprised the total forage yield because Illinois bundleflower failed to establish.

Illinois bundleflower persistence and yield in 1997 varied by site, despite initial similarities in seedling densities across the three study sites in 1996 (Table 2). This variability may have been influenced by annual grass interference and precipitation levels in 1996. At Clay Center, where annual grass interference with seedlings was high and 1996 Illinois bundleflower yields were usually less than $1.0 \mathrm{Mg} \mathrm{ha}^{-1}$, Illinois bundleflower yields were less than $0.3 \mathrm{Mg} \mathrm{ha}^{-1}$ in 1997, regardless of weed control treatment or seed mixture (Table 3 and 6). At Mead, Illinois bundleflower did not persist and no plants were found in 1997 (Table 4 and 6). High annual grass production and below-average precipitation at Mead during 1996 probably reduced Illinois bundleflower seedling growth and development, which led to poor survival in 1997. At Lincoln, where annual grasses were controlled during 1996, Illinois bundleflower yields in herbicide-treated areas averaged 3.3 $\mathrm{Mg} \mathrm{ha}^{-1}$ in 1997 (Table 5).

Burning in the spring of 1997 at Clay Center may have been another factor contributing to lower Illinois bundleflower yield compared with that observed at Lincoln, where residue was not burned. When sampled in 1997 at Clay Center, Illinois bundleflower stem density averaged $34 \mathrm{~m}^{-2}$ and dry matter averaged $0.2 \mathrm{Mg} \mathrm{ha}^{-1}$ (Table 6). At Lincoln, Illinois bundleflower seeded at

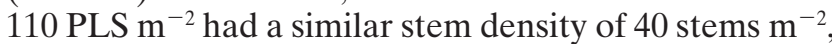
but yielded $1.6 \mathrm{Mg} \mathrm{ha}^{-1}$. Thus, burning at Clay Center may have increased big bluestem competition, thereby reducing Illinois bundleflower yield per stem. At the Mead site, burning did not affect yields of Illinois bundleflower in 1997 as no viable plants were observed.

These experiments provide evidence that imazapic and imazethapyr reduced weed interference and improved establishment and forage yields of big bluestem seeded with Illinois bundleflower. At all sites in 1996 and 1997, big bluestem yields were greater where imazapic was applied in the year of planting than where no herbicide was applied. At Lincoln in 1997, Illinois bundleflower and total forage yields were greatest where imazapic or imazethapyr was applied in 1996. In contrast, fall panicum interference at Mead and Clay Center appeared to reduce Illinois bundleflower growth and establishment in 1996, and contributed to the failure of Illinois bundleflower to persist into 1997 at Mead.

The effects of the seeding rates were less consistent across sites in part because of the low yields at Clay Center and poor survival at Mead of Illinois bundleflower. At Clay Center and Lincoln, total forage yields in 1997 were highest where big bluestem was seeded at 220 or $165 \mathrm{PLS} \mathrm{m}^{-2}$. Based on 1997 yields at the Lincoln site, Illinois bundleflower comprised 18 and $28 \%$ of the total forage in these mixtures. Further evaluation is needed to determine the appropriate proportion of Illinois bundleflower required to optimize forage quality and persistence in binary mixtures.

Imazapic and imazethapyr can be used to improve the establishment of big bluestem planted with Illinois

Table 5. Illinois bundleflower (IB), big bluestem (BB), and total forage (BB + IB) yields measured in the establishment year (1996) and the year after planting (1997) as affected by herbicide main effect or herbicide $\times$ seed mixture interaction at a site near Lincoln, $N E$.

\begin{tabular}{|c|c|c|c|c|c|c|c|c|c|}
\hline \multirow[b]{3}{*}{ Herbicide } & \multirow[b]{3}{*}{ Rate } & \multicolumn{5}{|c|}{1996} & & & \\
\hline & & \multirow[b]{2}{*}{ IB } & \multirow[t]{2}{*}{$\operatorname{Mix} 1 \dagger$} & Mix 2 & Mix 3 & \multirow[b]{2}{*}{$\mathbf{B B}+\mathbf{I B}+$} & \multicolumn{3}{|c|}{1997} \\
\hline & & & & \multicolumn{2}{|l|}{ BB } & & IB $¥$ & BB & $\mathbf{B B}+\mathbf{I B}+$ \\
\hline & & & & & & $1 a^{-1}$ & & & \\
\hline Imazapic & 70 & 3.5 & 1.6 & 3.5 & 4.3 & 6.3 & 3.4 & 8.3 & 11.7 \\
\hline Imazethapyr & 70 & 4.2 & 0.5 & 1.0 & 3.0 & 5.7 & 3.3 & 6.9 & 10.1 \\
\hline Nontreated & 0 & 0.2 & 0.1 & 0.2 & 0.5 & 0.5 & 0.6 & 1.2 & 1.8 \\
\hline LSD $(0.05)$ & & 0.7 & & 0.8 & 0.0 & 1.3 & 0.9 & 2.2 & 2.2 \\
\hline
\end{tabular}

$\dagger$ Mix 1 = 110 BB +220 IB pure live seed (PLS) m $^{-2}$; Mix $2=165$ BB +165 IB PLS m m $^{-2}$ Mix $3=220$ BB +110 IB PLS m ${ }^{-2}$.

$\uparrow$ Data are averaged across seed mixtures because herbicide $\times$ seed mixture interaction was not significant. 
Table 6. Illinois bundleflower (IB) stem density and yield, and big bluestem (BB) and total (BB + IB) forage yields in the second growing season (1997) as influenced by seed mixture main effect.

\begin{tabular}{|c|c|c|c|c|}
\hline \multirow[b]{2}{*}{ Mixture } & \multirow[b]{2}{*}{ IB stem density } & \multicolumn{3}{|c|}{ Forage Yield } \\
\hline & & IB & BB & $\mathbf{B B}+\mathbf{I B}$ \\
\hline & no. $\mathbf{m}^{-2}$ & 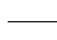 & Mg & - \\
\hline \multicolumn{5}{|l|}{ Clay Center } \\
\hline Mix $1 \dagger$ & 59 & 0.28 & 3.4 & $-\dot{t}$ \\
\hline Mix 2 & 19 & 0.11 & 4.2 & - \\
\hline Mix 3 & 24 & 0.11 & 4.3 & - \\
\hline LSD (0.05) & NS & 0.15 & NS & - \\
\hline \multicolumn{5}{|l|}{ Mead } \\
\hline Mix 1 & $\mathbf{0}$ & $\mathbf{0}$ & 4.2 & 4.2 \\
\hline Mix 2 & $\mathbf{0}$ & 0 & 4.0 & 4.0 \\
\hline Mix 3 & 0 & $\mathbf{0}$ & 4.0 & 4.0 \\
\hline LSD (0.05) & NS & NS & NS & NS \\
\hline \multicolumn{5}{|l|}{ Lincoln } \\
\hline Mix 1 & 97 & 3.5 & 3.4 & 6.9 \\
\hline $\operatorname{Mix} 2$ & 57 & 2.2 & 5.6 & 7.8 \\
\hline Mix 3 & 40 & 1.6 & 7.5 & 9.1 \\
\hline LSD (0.05) & 26 & 1.0 & 1.5 & 1.3 \\
\hline
\end{tabular}

$\dagger$ Mix $1=110 \mathrm{BB}+220$ IB pure live seed (PLS) $\mathrm{m}^{-2}$; Mix $2=165 \mathrm{BB}+$ 165 IB PLS m ${ }^{-2}$; Mix $3=220$ BB + 110 IB PLS $^{-2}$.

$\$$ There was a significant herbicide $\times$ seed mixture interaction for total forage yield at Clay Center.

bundleflower. Because other native warm-season grasses and legumes have exhibited tolerance to imidazolinone herbicides (Beran et al., 1999; Masters et al., 1996), mixtures containing additional species should be evaluated. These species could complement the characteristics of Illinois bundleflower and big bluestem and provide a resilient, high-quality, warm-season forage resource that could be reliably established on marginal cropland and degraded rangeland.

\section{REFERENCES}

Anderson, B. 1989. Establishing dryland forage grasses. NebGuide G81-534. Nebraska Coop. Ext., Univ. of Nebraska, Lincoln.

Beran, D.D, R.A. Masters, and R.E. Gaussoin. 1999. Establishment of grassland legumes with imazethapyr and imazapic. Agron. J. 91:592-596.

Berg, W.A. 1990. Native forb establishment and persistence in a grass forb seeding in the southern plains. p. 179-181. In D.D. Smith and C.A. Jacobs (ed.) Proc. 12th N. Am. Prairie Conf., Cedar Falls, IA. 4-9 Aug. 1990.Univ. Northern Iowa, Cedar Falls.

Daubenmire, R.F. 1959. A canopy-coverage method of vegetational analysis. Northwest Sci. 33:43-64.

Dovel, R.L., M.A. Hussey, and E.C. Holt. 1990. Establishment and survival of Illinois bundleflower interseeded into an established kleingrass pasture. J. Range Manage. 43:153-156.

George, J.R., K.M. Blanchet, R.M. Gettle, D.R. Buxton, and K.J. Moore. 1995. Yield and botanical composition of legume- interseeded vs. nitrogen-fertilized switchgrass. Agron. J. 87: $1147-1153$.

Hartley, H.O. 1950. The maximum $F$-ratio as a short-cut test for heterogeneity of variance. Biometrika 37:308-312.

Holt, E.C. 1984. Seed weight and plant vigor in Illinois bundleflower p. 160-168. In Forage research in Texas. Tex. Agric. Exp. Stn. CPR-4253, Texas A\&M Univ., College Station.

Jung, G.A., J.L. Griffin, R.E. Kocher, J.A. Shaffer, and C.F. Gross 1985. Performance of switchgrass and bluestem cultivars mixed with cool-season species. Agron. J. 77:846-850.

Krueger, C.R., and D.C. Curtis. 1979. Evaluation of big bluestem, indiangrass, sideoats grama, and switchgrass pastures with yearling steers. Agron. J. 71:480-482.

Latting, J. 1961. The biology of Desmanthus illinoensis. Ecology. 42:487-493.

Lentner, M., and T. Bishop. 1993. Experimental design and analysis. Valley Book Co., Blacksburg, VA.

Martin, A.R., R.S. Moomaw, and K.P. Vogel. 1982. Warm-season grass establishment with atrazine. Agron. J. 74:916-920.

Masters, R.A. 1995. Establishment of big bluestem and sand bluestem cultivars with metolachlor and atrazine. Agron. J. 87:592-596.

Masters, R.A. 1997. Influence of seeding rate on big bluestem establishment with herbicides. Agron. J. 89:947-951.

Masters, R.A., S.J. Nissen, R.E. Gaussoin, D.D. Beran, and R.N. Stougaard. 1996. Imidazolinone herbicides improve restoration of Great Plains grasslands. Weed Technol. 10:392-403.

Ott, L. 1977. An introduction to statistical methods. Duxbury Press, Belmont, CA.

Piper, J.K. 1993. Soil water and nutrient change in stands of three perennial crops. Agron. J. 57:497-505.

Posler, G.L., A.W. Lenssen, and G.L. Fine. 1993. Forage yield, quality, compatibility, and persistence of warm-season grass-legume mixtures. Agron. J. 85:554-560.

Schramm, P. 1992. Prairie restoration: A twenty-five year perspective on establishment and management. p. 169-177. In D.D. Smith and C.A. Jacobs (ed.) Proc. 12th N. Am. Prairie Conf. Univ. of Northern Iowa, Cedar Falls.

Schweitzer, S.H., F.C. Bryant, and D.B. Wester. 1993. Potential forage species for deer in the southern mixed prairie. J. Range Manage. 46:70-75.

Taylor, T.H., and L.T. Jones. 1983. Compatibility of switchgrass with three sod-seeded legumes. p. 15. In Ky. Agric. Exp. Stn. Prog. Rep. Univ. of Kentucky, Lexington.

Townsend, C.E., G.O. Hinze, W.D. Ackerman, and E.E. Remmenga. 1975. Evaluation of forage legumes for the central Great Plains. Colo. Exp. Stn. Gen. Ser. 942, Colorado State Univ., Fort Collins.

Turner, K.E., J.G. Foster, and D.P. Belesky. 1997. Nutritive value of some non-traditional forage plants. p. 212-216. In M.J. Williams and M. Phillips (ed.) Proc. Am. Forage and Grassl. Counc., Fort Worth, TX. 13-15 Apr. 1997. AFGC, Georgetown, TX.

Vogel, K.P., R.A. Masters, P.J. Callahan, and K.G. Grams. 1998 Rotary processor for chaffy prairie grass seed. J. Range Manage. 51:536-539.

Wasser, C.H. 1982. Illinois bundleflower. p. 500-503. In Ecology and culture of selected species useful in revegetating disturbed lands in the West. U.S. Dep. Int. Fish and Wildl. Serv., Washington, DC.

Weaver, J.E. 1954. North American prairie. Johnsen Publishing Co., Lincoln, NE. 